\title{
"Baptism of Repentance for the Remission of Sins". Mark 1:4 in Its Context
}

\author{
ARTUR MALINA \\ University of Silesia in Katowice \\ artur.malina@us.edu.pl \\ ORCID: 0000-0002-2830-9902
}

\begin{abstract}
The titular term commonly refers to the baptism administered by John. In the other earliest sources, forgiveness of sins is not closely linked to washing with water performed by him, as the description of the Baptist's appearance in the Gospel of Mark seems to suggest. The analysis of the verse marked in the title leads to the conclusion that Mark characterizes John's appearance by two conjoined activities: baptizing and preaching which are expressed by the participles $\beta \alpha \pi \tau i \zeta \omega v$ and $\kappa \eta \rho v ́ \sigma \sigma \omega v$. The first one allows for diagnosing the state of relations between humans and God. This diagnosis is expressed through the confession of their sins. The second one announces to them a therapy appropriate to the position they have identified. This therapy is supposed to be the baptism of repentance for the forgiveness of sins preached by John, equating with the future baptism in the Holy Spirit.
\end{abstract}

KeYwords: Gospel of Mark, John the Baptist, Baptism of Jesus, Biblical soteriology, Remission of sins

G ospel of Mark presents two of John's activities in parallel: baptizing in the desert and preaching the baptism of repentance for the forgiveness of sins. ${ }^{1}$ The importance of this juxtaposition is not obvious. Did John preach his baptism, and those baptized by him receive the baptism of repentance? ${ }^{2}$ Or per-

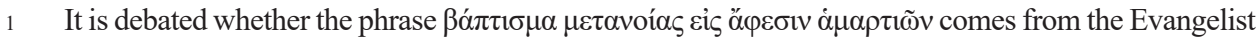
himself or from the circle of John the Baptist. John P. Meier (A Marginal Jew, Rethinking the Historical Jesus. II. Mentor, Message, and Miracles [New Haven, CT - London: Yale University Press 1994] 53-54) supposes that some of John's disciples, when they became followers of Jesus, may have introduced it into the Gospel tradition without relating it to Christian baptism.

2 In this manner, J. Marcus, Mark 1-8. A New Translation with Introduction and Commentary (New York: Doubleday 2000) 164: "The object of John's initial proclamation is his baptism"; M. Trimaille, La christologie de Saint Marc (Paris: Desclée 2001) 72: "[...] les foules ont accouru de toute la Judée et de Jérusalem à son baptême de repentance (v. 5)"; cf. also: J.R. Donahue - D.J. Harrington, The Gospel of Mark (Collegeville, MN: Liturgical Press 2002) 62; J.R. Edwards, The Gospel According to Mark (Grand Rapids, MI - Cambridge: Eerdmans 2002) 31; F. Hahn, Theologie des Neuen Testaments. I. Die Vielfalt des Neuen Testaments. Theologiegeschichte des Urchristentums (Tübingen: Mohr Siebeck 2002) 48; J.D.G. Dunn, Jesus Remembered (Grand Rapids, MI: Eerdmans 2003) 358; K. Stock, Marco. Commento contestuale al secondo Vangelo (Roma: Edizioni 
haps even this ritual granted them forgiveness of sins $?^{3}$ However, affirmative answers to these questions do not agree with other first-century testimonies of the Baptist. Careful reading of the Gospel of Mark confirms that it does not identify water baptism with the baptism preached by John either and assigns the power of forgiveness of sins only to the latter.

\section{Baptism by John and the Forgiveness of Sins outside Gospel of Mark}

In Matthew's narrative of the Baptist, there is no mention of forgiving sins. Although Luke conveys Mark's wording about the baptism of repentance preached by John, he links the forgiveness of sins with the person of Jesus and with His ministry continued by His disciples. The issue of the relationship between the ritual performed by John and the liberation from sins is also addressed by Josephus Flavius. ${ }^{4}$

ADP 2003) 20; M. Mullins, The Gospel of Mark. A Commentary (Dublin: Columba Press 2005) 62; C.S. Keener, The Historical Jesus of the Gospels (Grand Rapids, MI - Cambridge: Eerdmans 2009) 167; D. Bock, Mark (Cambridge: Cambridge University Press 2015) 111; P. Mascilongo, Il Vangelo di Marco. Commento esegetico e teologico (Roma: Città Nuova Editrice 2018) 127; F. Filannino, Tra il precursore e i discepoli. La missione di Gesù nel vangelo di Marco (Roma: Gregorian \& Biblical Press 2019) 39-40. In the same way, Jesus was to have received this baptism preached by John R.T. France, The Gospel of Mark. A Commentary on the Greek Text (Grand Rapids, MI - Cambridge: Eerdmans 2002) 67: "Mark betrays no doctrinal embarrassment over the fact that Jesus, the Son of God, who is repeatedly described in the NT writings and in later Christian orthodoxy as sinless,

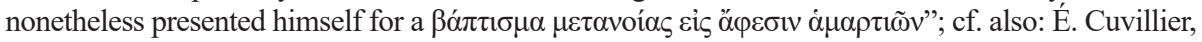
L'évangile de Marc (Paris - Genève: Labor et Fides 2002) 27; L. Schenke, "Jesus und Johannes der Täufer," Jesus von Nazaret - Spuren und Konturen (eds. L. Schenke et al.) (Stuttgart: Kohlhammer 2004) 85; A. Puig i Tàrrech, "Pourquoi Jésus at-il reçu le baptême de Jean?," NTS 54/3 (2008) 356-357; E. Ferguson, Il battesimo nella chiesa antica. Storia, teologia e liturgia nei primi cinque secoli. I. I primi due secoli (Brescia: Paideia 2014) 109; E.J. Schnabel, Mark. An Introduction and Commentary (Downers Grove, IL: InterVarsity Press 2017) 45.

3 In this manner B. Witherington III, The Gospel of Mark. A Socio-Rhetorical Commentary (Grand Rapids, MI - Cambridge: Eerdmans 2001) 72: "[John] seems to have been offering forgiveness without sacrifice being offered in the temple. He was offering remission of sins without connection to the hierarchical system in Jerusalem"; cf. also: S. Grasso, Vangelo di Marco. Nuova versione, introduzione e commento (Milano: Paoline 2003) 44; C. Focant, L'évangile selon Marc (Paris: Cerf 2004) 64; G. Shafer, "John the Baptist, Jesus, and Forgiveness of Sins," Eastern Great Lakes and Midwest Biblical Society Proceedings 26 (2006) 51-53; P. Dschulnigg, Das Markusevangelium (Stuttgart: Kohlhammer 2007) 62; G. Guttenberger, Das Evangelium nach Markus (Zürich: Theologischer Verlag 2017) 35.

4 Despite some similarities between the baptism of John and the ablutions performed in Judaism (especially as attested by the writings of Qumran), the article omits the comparison with other sources not so much because of significant differences (cf. J. Marcus, John the Baptist in History and Theology [Columbia, SC: University of South Carolina 2018] 27-45), but for the reason that none of these 


\subsection{Josephus Flavius}

Regardless of the evangelical tradition, Josephus Flavius (Ant. 18, 116-117) mentions John's activities and his baptism, citing the opinion of some Jews on the cause of the defeat suffered by Herod Antipas at the battle with Aretas IV at Gamala in Perea. According to them, this defeat was God's punishment for killing "John called the Baptist" ('I cient Jewish historian calls him a "good man" ( $\alpha \gamma \alpha \theta \dot{o} v$ ö $v \delta \rho \alpha)$, who appealed for practicing virtue, mutual justice and piety toward God as he addressed those benefiting $^{6}$ from his baptism. Josephus Flavius explains the difference between the forgiveness of sins and washing with water as follows: the liberation from sins did not depend on the ritual of the Baptist, and baptism was received from him only for the sanctification of the body, while the purification of the soul took place even before this rite with the beginning of a righteous life.

\subsection{Gospel of Matthew}

The first Gospel links the forgiveness of sins not with John's activity, as the other

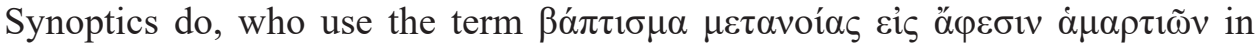
the account thereof (Mark 1:4; Luke 3:3), but exclusively with the person and work of Jesus. ${ }^{7}$ At the very beginning of it, the angel of the Lord announces

sources bear witness to the reception of John's activity, as the passage from Josephus Flavius and the narrative texts of the New Testament do. The fourth Gospel presents John who directly points to Jesus removing the sin of the world, which is the ignorance of the Word by people but does not link his activity with the remission of sins (as in John 20:23 in the plural) (John 1:29; cf. 1:10.26).

5 The authenticity of the entire fragment (Ant. 18:116-119), devoted to the activity and circumstances of John the Baptist's death as coming from Josephus Flavius, is widely accepted following Meier, A Marginal Jew, 19. A critical evaluation of both the arguments for its authenticity and the possibility of undermining it is conducted in a detailed study of this passage by Clare K. Rothschild ("'Echo of a Whisper'. The Uncertain Authenticity of Josephus' Witness to John the Baptist," Ablution, Initiation, and Baptism. Late Antiquity, Early Judaism, and Early Christianity / Waschungen, Initiation und Taufe. Spätantike, Frühes Judentum und Frühes Christentum [eds. D. Hellholm et al.] [Berlin Boston, MA: De Gruyter 2011] I, 255-290).

6 It cannot be concluded from Josephus Flavius' account that John personally baptized with water, for he portrays him as "recommending" ( $\kappa \varepsilon \lambda \varepsilon v ́ o v \tau \alpha)$ adoption of the right attitude toward people and God; cf. I. Gruenwald, "The Baptism of Jesus in Light of Jewish Ritual Practice," Neot 50/2 (2016) 318-319.

7 Cf. L. Hartman, "Into the Name of the Lord Jesus". Baptism in the Early Church (Edinburgh: Clark 1997) 17: "Matthew focuses on the preaching of repentance and indirectly denies that John's baptism was for the forgiveness of sins; instead, it is presented only as a baptism 'in water for repentance' (3.11). [...] The forgiveness of sins is instead given by Jesus and through his work; thus, Jesus' name is explained by the statement that 'he will save his people from their sins' (1.21), and Matthew also mediates the liturgical tradition whereby Jesus' blood is 'poured out for many for the forgiveness of sins' (26.28)"; T. Costin, Il perdono di Dio nel Vangelo di Matteo. Uno studio esegetico-teologico 
liberation from sins when he explains the meaning of His name (Matt 1:21). Near its end, in Jesus' words about His blood poured out for the forgiveness of sins there even appears the same prepositional phrase eì $\alpha$ $\varphi \varepsilon \sigma v v \dot{\alpha} \mu \alpha \rho \tau \imath \tilde{\omega} v$ (Matt 26:28) which, according to Mark and Luke, characterizes the baptism preached by John.

The difference is also evident in the narrative about John the Baptist itself in the Gospel of Matthew. The definitely positive sense of the mention of the forgiveness of sins would not fit the image of the addressees of his activity in this Gospel. Those baptized by him in Jordan admittedly confess their sins (Matt 3:6). However, the Baptist's speech is dominated by threats directed at the Pharisees and Sadducees. He first accuses them of trying to escape the coming wrath (Matt 3:7), and then he formulates a double exhortation: positive - to produce fruit in keeping with repentance (Matt 3:8); negative - to reject the conviction of the importance of their ties with Abraham (Matt 3:9). The threats are expressed in two images: the first, a fruitless tree thrown into a fire (Matt 3:10); the second - the chaff burned in unquenchable fire (Matt 3:12). Placed between them,

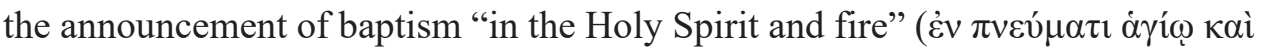
$\pi v \rho i$ ) (Matt 3:11) is not associated with the promise of forgiveness of sins, since the addressees of this announcement are accused of not repenting. ${ }^{8}$

\subsection{Gospel of Luke}

The Gospel of Luke parallels Mark's text in the part of its summary description of John's activity as preaching the baptism of repentance for the forgiveness of sins, while it distances itself from both Synoptics in its depiction of the baptism with water. John's speeches are in the foreground in this book, and his baptismal activity is merely a background to them. Matthew and Mark report people

(Roma: Editrice Pontificia Università Gregoriana 2006) 63: "È da ritenere che il riferimento sia omesso da Matteo a causa della sua nuova formulazione della proclamazione del Battista al v. 2, in parallelo a quella di Gesù (3.17). Egli non utilizza la parola «perdono», forse perché una caratteristica dell'opera di Gesù, troppo centrale per essere associata ad un altro $(1,21 ; 26,28)$."

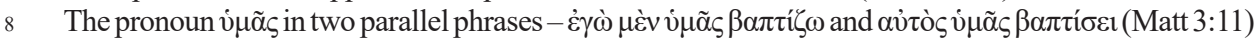
- refers to the Pharisees and Sadducees who are the only listeners of all John's speech (Matt 3:7-12). However, some Bible editions and commentaries suggest a change of addressee because they distinguish two parts as if they were two separate speeches: 3:7-10 and 3:11-12. The latest editions of Nestle-Aland, Novum Testamentum Graece divide the Matthew's text in the same way. This division is encouraged by harmonization with the third Gospel which contains John's dialogues with groups of his listeners (Luke 3:10-14) between the parallel passages (Luke 3:7-9; 3:15-18). This influence can be seen in K. Aland (ed.), Synopsis Quattuor Evangeliorum. Locis parallelis evangeliorum apocryphorum et patrum adhibitis, 15 ed. (Stuttgart: Deutsche Bibelgesellschaft 1996), which distinguishes for Matthew 3:7-10 a pericope entitled "Bußpredigt Johannes des Täufers," and for Matthew 3:11-12 - "Ankündigung des Messias durch Johannes." 
going out from their dwelling places and undergoing the ablution with water in the Jordan, accompanied by their confession of sins (Matt 3:5-6; Mark 1:5). The third Gospel barely mentions baptism with water in the introductions to John's speeches, which identify their addressees as coming to him in order to be baptized (Luke 3:7.12). ${ }^{9}$

Also, in the case of Luke, commentators identify the baptism of repentance for the forgiveness of sins with the baptism in Jordan. ${ }^{10}$ This approach comes from considering the narrative of John's activity without connections to the Infancy Gospel (Luke 1:5-2:52). The beginning of the narrative about the Baptist with the characteristics of its protagonist as the son of Zechariah (Luke 3:3) refers to the first chapters of the Gospel. ${ }^{11}$ In these two chapters are the essential features of John's mission presented. In the hymn Zechariah foretells the future of the new-born child: he calls him the prophet of the Most High; announces that he will go before the Lord and prepare His ways (Luke 1:76); says that the purpose of John's mission would be to give people the knowledge of salvation through the forgiveness of their sins (Luke 1:77). The information given immediately before Jesus' baptism whereby all the people were baptized confirms the accomplishment of the Baptist's mission (Luke 3:21). Luke presents John's activities in such a way as to show that Zechariah's words are completely fulfilled in them. ${ }^{12}$

9 The correct interpretation of the changes in the Gospel of Luke is given by Richard J. Dillon ("The Benedictus in Micro- and Macrocontext," CBQ 68 [2006] 477): "[Luke] eliminates Mark's report of the actual baptizing of crowds of people by John and of the confession of sins by the baptized [...] Luke systematically pushes John's baptizing into the background, even excluding him from the scene of Jesus' baptism [...] He emphasizes, instead, John's preaching." However, Dillon's expla-

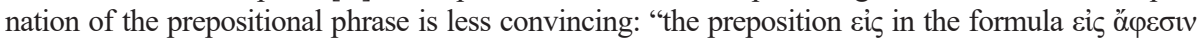
$\dot{\alpha} \mu \alpha \rho \tau \imath \tilde{\omega} v$ expresses the «pointing-forward» effect of John's proclamation - «toward the forgiveness of sins»" (ibidem, 478). The preposition refers not to the effect of John's proclamation, but to the effect of its most important content, namely the activity of Jesus bringing the forgiveness of sins.

10 Most often this happens without any attempt to justify this identification; compare: I.H Marshall, The Gospel of Luke. A Commentary on the Greek Text (Grand Rapids, MI: Paternoster Press - Eerd-

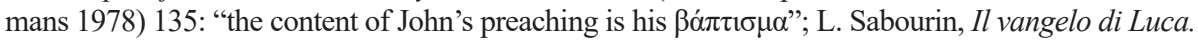
Introduzione e Commento (Roma: Editrice Pontificia Università Gregoriana 1989) 119: “[...] come spiegare che Gesù si sia sottomesso ad un battesimo di conversione?"; S. Grasso, Luca (Roma: Borla 1999) 127: "[...] egli viene battezzato dal profeta con un battesimo di conversione e perdono dei peccati"; R. Meynet, Il Vangelo secondo Luca. Analisi retorica (Bologna: Dehoniane 2003) 153: "Il battesimo di Giovanni è «un battesimo di conversione per la remissione dei peccati» $(3,3)$."

11 Cf. M. Wenk, Community-Forming Power. The Socio-Ethical Role of the Spirit in Luke - Acts (Sheffield: Sheffield Academic Press 2000) 175, 176: "In 3.3 Luke introduces John as the Son of Zechariah, while both Mark and Matthew refer to him as 'John the Baptist' (cf. Mk 1.4; Mt 3.1). This is perhaps Luke's way of underlining for his readers the link between the infancy narratives, especially Lk 1.13-17, and John's ministry."

12 Wenk, Community-Forming Power, 176: "John is presented as fulfilling the role that was anticipated in the infancy narratives." On the other hand, the connection between Zechariah's words about the knowledge of salvation in the forgiveness of sins (Luke 1:76-77) with John's preaching of repentance (Luke 3:3) is correctly indicated by Jorge Humberto Morales Ríos ("Visita e antropologia nel Benedictus [Lc 1,67-79]," Antonianum 94 [2019] 13-24). 
The source of the forgiveness of sins flowing from Jesus is indicated by

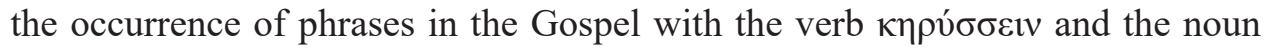

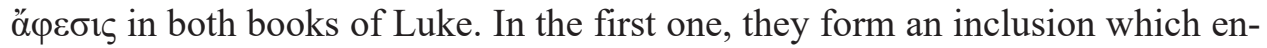
compasses all of Jesus' earthly deeds. At the beginning, Jesus refers to the proph-

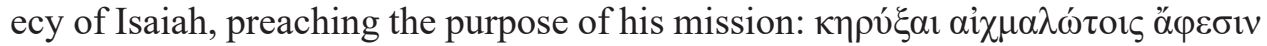
(Luke 4:18; cf. Isa 61:1). By opening the disciples' minds to understand the Scriptures after his resurrection, Jesus proclaims to them the fulfilment of his promise to preach in His name repentance for the forgiveness of sins to all nations:

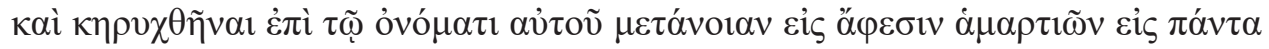
$\tau \grave{\alpha}$ है $\theta v \eta$ (Luke 24:47). In the second book of Luke, the repeated appearance of the same phrases confirms that the forgiveness of sins is given through Jesus, in His name, and through faith in Him (Acts 2:38; 5:31; 10:43; 13:38; 26:18).

\subsection{The Preliminary Conclusion}

Matthew and Luke do not identify the baptism of repentance for the forgiveness of sins with water baptism. The first does not mention the forgiveness of sins at all in the narrative of John's activities. The second one, demoting administration of water baptism to the background, places in the foreground his proclamation as the fulfilment of Zechariah's words. Owing to the Baptist's speeches, the people learn about salvation being close at hand in the forgiveness of sins.

Does the separation of the forgiveness of sins from baptism with water, especially conspicuous in the Gospel of Matthew, contradict the image of John's activity in the Gospel of Mark? ${ }^{13}$ The answer is not obvious. Discrepancies in conveying the text by copyists and between the translations, on the one hand, indicate difficulties in the perception of this image, and on the other hand, they result from the tendency to harmonise Mark's text with the other Synoptics.

\section{Problems with the Principal Meaning of Mark 1:4}

13 This opinion is expressed by Chong-Hyon Sung (Vergebung der Sünden. Jesu Praxis der Sündenvergebung nach den Synoptikern und ihre Voraussetzungen im Alten Testament und frühen Judentum [Tübingen: Mohr Siebeck 1993] 206): "Die matthäische Gemeinde hatte Schwierigkeiten mit dem Ausdruck «Taufe zur Vergebung der Sünden». Matthäus unterdrückt ihn darum bewußt (Mt 3,2) und fügt das Stichwort «Sündenvergebung» erst in den Abendmahlszene ein (Mt 26,28; nicht bei Mk, Lk und Joh). Matthäus glaubt also nicht an die sündenvergebende Wirkung der Johannestaufe." The same difficulty is indicated by Simon Légasse ("L'autre «baptême» [Mc 1,8; Mt 3,11; Lc 3,16; Jn 1,26.31-33]," The Four Gospels 1992. Festschrift Frans Neirynck [eds. F. van Segbroeck et al.] [Leuven: University Press 1992] I, 259). 
Difficulties lie in understanding of the verse itself which presents baptising and preaching as a dual characteristic of John's appearance. The only predicate in it

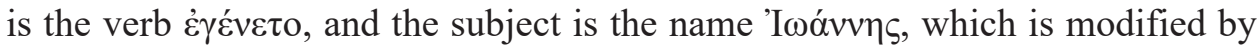
two participles: $\beta \alpha \pi \tau i \zeta \omega v$ and $\kappa \eta \nu v \sigma \sigma \omega v$. The activities marked have the same rank and duration within the period of time. It is not easy to capture the meaning of this relationship between them.

\subsection{Difficulties in the Transmission of the Text}

The manuscripts and translations harmonise the concise description of John's activity with its image in Matthew and Luke, and with the popular image of the desert as a place without water. This harmonisation consists not so much in reconciling individual words (Mark 1:4 does not have strict synoptic parallels) but in moving preaching to the foreground before baptism (Matt 3:1: $\pi \alpha \rho \alpha \gamma i v \varepsilon \tau \alpha$ l

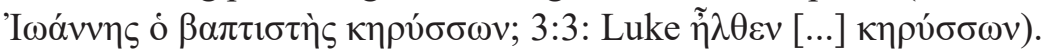

In Mark's text, baptismal activity is implied by the participle $\beta \alpha \pi \tau i \zeta \omega v$, but it is often understood as a title: "Baptist" or "Baptizer."14 This interpretation corresponds to the omission of the conjunction $\kappa \alpha$ í in some manuscripts (in, i.a., B, 33, 892, 2427 and in a few Bohairic ones). The variant that presents John the Baptist's appearance in the desert as only proclaiming baptism there, and not as baptising there as well, is influenced by the popular association of the noun "desert"

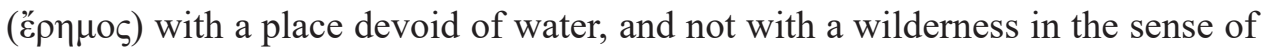
an uninhabited area. ${ }^{15}$

The presence of the conjunction kai between the two participles and the article o before the first is attested in better manuscripts ( $\mathrm{N}, \mathrm{L}, \Delta^{16}$ and most of the Bo-

14 The participle as the title is translated by: RSV/NRSV: "John the baptizer appeared in the wilderness, proclaiming a baptism of repentance for the forgiveness of sins"; NAB/NABO: "John [the] Baptist appeared in the desert proclaiming a baptism of repentance for the forgiveness of sins"; NAS: "John the Baptist appeared in the wilderness preaching a baptism of repentance for the forgiveness of sins"; NIV: "And so John the Baptist appeared in the wilderness, preaching a baptism of repentance for the forgiveness of sins" (translation tags and text from Bible Works for Windows 9.0).

15 The latter, the correct meaning here is confirmed by the immediate context. In the next verse, the in-

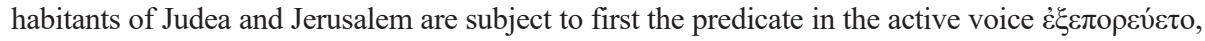
which depicts their appearance to John as leaving their places of residence, and then the predicate in the passive voice $\dot{\varepsilon} \beta \alpha \pi \tau i \zeta$ ovto, which denotes receiving ablution "in the Jordan River"

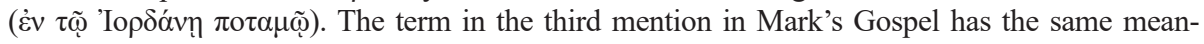
ing. Although Jesus comes to the Jordan to be baptized by John (Mark 1:9), after the theophany,

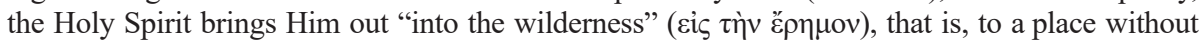
human presence, which the Jordan area could not have been, being filled with the inhabitants of the land of Judah and Jerusalem. The mention of Jesus' sojourn with wild animals corresponds with this second meaning of the wilderness as an uninhabited region (Mark 1:13).

16 The Codex Sangallensis in the case of the Gospel of Mark belongs to a good witness since in this Gospel it also includes, though not exclusively, variants of the Alexandrian type, while in the other 
hairic ones). Its presence is confirmed, omitting the article and in some cases changing the order of words, by other numerous though weaker pieces of evidence (in, i.a. A, D, K, P, W, $\Gamma, \mathrm{Y}, \Theta, \Pi, \Omega, f^{1.13}, 28,700,565,579,1241,1424$, $2542, \ell 844, \ell 2211$ many Byzantine ones and from translations, i.a.: lat sy p.h.). The manuscript evidence supports the reading with an article before the first participle and with a conjunction between two segments with participles, so that the whole verse can be rendered: "John appeared baptizing in the wilderness and proclaiming a baptism of repentance for the remission of sins." When a participle occurs with the same predicate in Mark's narrative about the transfiguration of Jesus it also represents the action that accompanies the appearance of the cloud: "And a cloud appeared, overshadowing them" (Mark 9:7). ${ }^{17}$ On the other hand, in structures with two participles it occurs several times apart from the Gospel of Mark. Also in these cases it presents closely related actions: "killing the prophets and stoning those who are sent" (Matt 23:37; Luke 13:34); "opening and no one will shut, and shutting and no one opens" (Rev $3: 7)$; "the one hearing and seeing these things" (Rev 22:8). The modern translations of these texts correctly render the actions as parallel and related to each other. On the other hand, in the case of Mark's text, some of them inconsistently translate the first participle as the title of John, and not as the designation of an activity which is parallel to the second action, and both characterise his appearance.

\subsection{Baptist or Baptizing}

The argument for understanding the participle $\beta \alpha \pi \tau i \zeta \omega v$ as a title is the use of this term in a way that may indicate its synonymity with the term "the Baptist" (o $\beta \alpha \pi \tau \imath \sigma \tau ́ \varsigma)$. This noun is a typical term for John in the remaining Synoptics (Matt 3:1;11:11.12; 14:2.8; 16:14; 17:13; Luke 7:20; 7:33; 9:19). Apart from the Gospel of Mark, the present participle occurs together with his name only

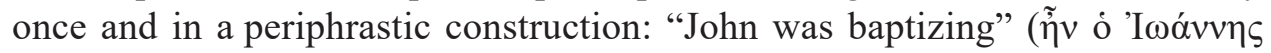
$\beta \alpha \pi \tau i \zeta \omega v)$ (John 1:28). When Mark speaks of John's appearance, then he uses the participle not to distinguish him from another John, the younger son of Zebedee and the brother of Jacob (Mark 1:19.29; 3:17; 5:37; 9:2.38; 10:35.41; $13: 3 ; 14: 33)$. For this purpose, he could have used a noun as a title which he uses elsewhere (Mark 6:25; 8:28). In these two texts, its use is only apparent-

Gospels the Byzantine text predominates; cf. P.W. Comfort, Encountering the Manuscripts. An Introduction to New Testament Paleography \& Textual Criticism (Nashville: Broadman \& Holman 2005) 85.

17 This is how it is rendered by the translations mentioned in $\mathrm{n} .14$ which in the reference to the John's appearance treat the participle as his title. 
ly equivalent to the other two cases of John being described by a participle (Mark 6:14; 8:28).

In the first case, Jesus performing miracles in Galilee is identified with John (Mark 6:14.16). The opinion about John's ongoing activity is based on the belief that he rose from the dead. People convinced of John's ongoing activity use the participle in apposition to his name. The mention of his rising from the dead introduces the narrative of his execution at the behest of Herod (Mark 6:17-29), who was also said to have shared their opinion (Mark 6:16). ${ }^{18}$ On the other hand, when the disciples are asked what people think about Jesus, they refer to popular beliefs, distancing themselves from the first identification ${ }^{19}$ since they do not use a participle form that would represent John's activity as being still in progress, but use a noun in the title function, which by association with his past activity, distinguishes him from other persons bearing the same name (Mark 8:28). ${ }^{20}$

The second case is analogous, although the synonymity of the participle and the noun as a title seems obvious. ${ }^{21}$ Herodias demands John's execution in a met-

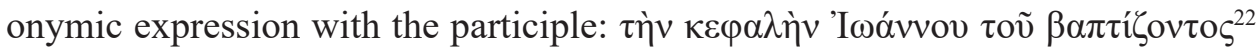

18 Mark does not present Herod as the main author of the opinion that John rose from the dead, but only as one accepting such identification of him with Jesus; cf. N. Vette - W. Robinson, "Was John the Baptist Raised from the Dead? The Origins of Mark 6:14-29," The Biblical Annals 9/2 (2019) $342-343$.

19 It is different with the second identification. Disciples do not distance themselves from people who identify Jesus with Elijah for two reasons. First, the prophet's name is quoted without additional terms for both the opinion of the people (Mark 6:15) and its presentation by the disciples (Mark 8:28). Second, the disciples coming down from the mount of transfiguration have difficulty precisely in understanding Elijah's role because of the doctrine of the scribes for whom resurrection understood as an event of the end times would be preceded by this prophet's coming. (Mark 9:11). This doctrine, on the one hand, contributed to the fact that some people identified Jesus with Elijah and not with John risen from the dead, and on the other hand, it was a hindrance for the disciples in understanding the command to remain silent about what they saw on the mount of transfiguration. The disciples, in a similar way to other (not all) Jews, were able to understand the resurrection only as an event of end times, and therefore inconsistent with Jesus' command, according to which their testimony to the transfiguration was to begin only after the resurrection of the Son of Man; cf. A. Malina, "Le ragioni del silenzio richiesto ai discepoli (Mc 8.30; 9.9)," Antonianum 91/1 (2016) 190-193.

20 This is the function possessed by the title $\beta \alpha \tau \tau \imath \tau \tau$ ' describes John as ,[that was] called the Baptist” ( moves on to the description of his activities (Ant. 18, 116-117). At the same time, he uses two syn-

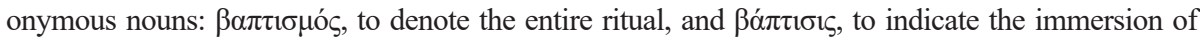
the body in water. This distinction is a result of the use of the two words in this particular passage, and does not depend on the permanent definition of their meaning as given by Richard C. Trench (Synonyms of the New Testament [London: Macmillan 1871] 356).

21 Cf. France, The Gospel of Mark, 65: "There is no obvious rationale for Mark's choice of title for John in the four other occurrences in the gospel $(6: 14,24,25 ; 8: 28)$, especially since ó $\beta \alpha \pi \tau i \zeta \omega v$ and $\dot{o}$

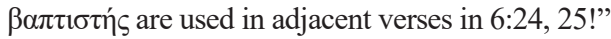

22 In numerous and later manuscripts it is replaced by the noun form $\beta \alpha \pi \tau \imath \sigma \tau o \tilde{v}$. If the reason for the change was to harmonize it with the immediate context only, then one would also expect a vari- 
(Mark 6:24). The claimant intends to break the influence exerted by John on Herod (Mark 6:18-20). The participle of the verb which denotes a characteristic type of John's activity is fitting for her words. On the other hand, the Herodias' daughter modifies her mother's wish by literally expressing her request and

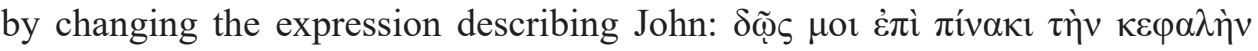

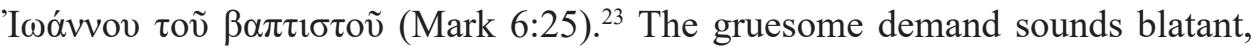
so that it could be verified: Herod is to give her the head of John the Baptist on a platter immediately. It would not be fitting for this particular demand to describe John as being active, that is, alive. On the other hand, a title that only identifies John by distinguishing him from others bearing the same name is consistent with the modified demand.

The recognition of the verbal meaning of the participle is fundamental for the correct understanding of the two components of the characteristics of John's appearance. Baptism and preaching, which are denoted by the participles $\beta \alpha \pi \tau i \zeta \omega v$ and $\kappa \eta \rho v \sigma \sigma \omega v$, are activities taking place at the same time and are in a certain way combined. Without the following verses their relationship would not be clear because of the conciseness of the description. ${ }^{24}$ Similarly, the summary descriptions of the beginning of Jesus' activity are also understated (Mark 1:14-15; 1:21-22). Their common feature is the lack of mentioning the addressees of the described activity, although their presence is implied due to the type of activity: in the first case, Jesus proclaims the Gospel of God in Galilee and calls for repentance and faith; in the second one, he teaches in the synagogue and arouses the amazement of those present in this place. Likewise, John is the only person described in this succinct description. It is only in the following verses that the interest of the Gospel reader is satisfied by expanding the topics indicated in the summary description and by introducing onto the stage of the developing narrative the addressees of the actions first mentioned only generally.

ant with the participle form in the demand for the immediate execution of John made by the daughter of Herodias because, up to this point, only this form was used three times to describe his name (Mark 1:4; 6:14.24). The variant with a participle in the daughter's demand is attested very poorly ( $\mathrm{L}, 700$ ), unlike the manuscript reading with a noun in Herodias' demand (A, C, D, E, F, G, H, K, M, N, S, W, Y, $\Pi, \Omega, 2,13,28,33,69,118,124,157,346,579,700,1071,1424,1582, f^{1.13}$ and others with Byzantine type text). The use of the variant with a noun is influenced by the exclusive presence of this title in texts in the other Synoptics.

23 Cf. B. Baert, "The Dancing Daughter and the Head of John the Baptist (Mark 6:14-29) Revisited. An Interdisciplinary Approach," LS 38/1 (2014) 14.

24 Cf. W.L. Lane, The Gospel According to Mark. The English Text with Introduction, Exposition and Notes (Grand Rapids, MI: Eerdmans 1974) 49: "The absence of qualifying clauses makes it difficult to ascertain the exact nuance in the phrase, «a baptism of conversion for the forgiveness of sins»." 


\section{Baptism Proclaimed by John}

The Evangelist presents John's activity, together with the reaction of its addressees, as a lasting situation, one that is stretched over time, and not as a series of single, consecutive events. The past imperfect tense and the lack of detailed chronological references fit the description of repeated, overlapping activities taking place over the same time span..$^{25}$ The relationship between the brief description of John's appearance and its extended part indicates that the baptism of repentance for the forgiveness of sins that John proclaimed is identical to the later baptism in the Holy Spirit. The extension of the description presents: people's egress from their places of living and reception of John's baptism (Mark 1:5); his clothing and diet (Mark 1:6); his address quoted in direct speech (Mark 1:7-8).

\subsection{Extension of the Description of Baptism (Mark 1:5)}

The addressees of John's activities are found in the foreground: "the whole Judean land and all the inhabitants of Jerusalem," because they are the grammatical subject of two predicates: "was going out" and "were being baptized." ${ }^{26}$ These two activities correspond to the first description of John's appearance: "baptizing in the desert." Leaving their places of residence is necessary for people in order to be at the venue where he acted, that is, in the wilderness in the sense of an uninhabited place, and to be baptized by him in the Jordan River.

The egress of the inhabitants of the Judean land and Jerusalem is clearly distinguished from the coming of Jesus (Mark 1:9). His coming differs from the sense of changing place on the part of all other people. ${ }^{27}$ Their translocation is to be interpreted within the typology of the Israelites' exodus from Egypt, that is, it is presented as new liberation - this time from the bondage of sins. Of course, Jesus could not have been the subject of such egress. His way to the Jordan River

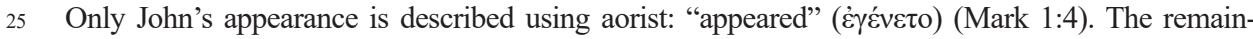

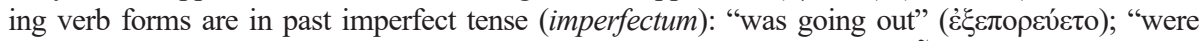

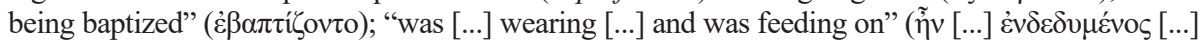

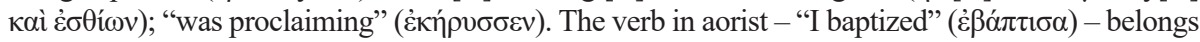
to John's speech, quoted in direct speech (Mark 1:7-8).

26 When a collective subject consists of the first singular element and the second plural element, the predicate occurring before the collective subject is singular (Mark 1:36; 3:31a; 8:27), and plural when it follows it (Mark 3:3.31b.32); cf. BDR §135.1.

27 The use of the same verb in John's speech and in the account of Jesus' first appearance (Mark 1:8,9) distinguishes Mark from the other Synoptics. The first Gospel simply speaks of His appearance by the Jordan River (Matt 3:13, despite John's announcement using this verb in Matt 3:11). The third Gospel omits any mention of His appearance, presenting His baptism in the Jordan River together with the baptism of others (Luke 3:21, despite the announcement in Luke 3:16). 
does not refer to the idea of returning to the desert in the sense of repentance. This radical difference is confirmed by the events surrounding the baptism of Jesus, who has no sins to confess. Because of this "delayed" coming, He is not the addressee of the proclamation of baptism in the Holy Spirit, because He is to be the subject of this baptism and not its addressee. His coming is the beginning of the Lord's path as presented in the combined quotation at the beginning of the Gospel (Mark 1:2-3). ${ }^{28}$

Confession of sins is represented by the Greek present participle in the phrase

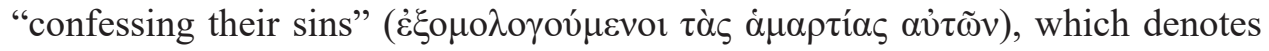
an action accompanying the main action indicated by the main verb in the past

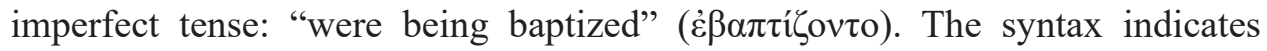
the simultaneity of baptism in the Jordan River and confession of sins, so that their confession cannot be considered a condition for baptism with water. The ritual of washing with water cannot be a consequence of confessing the sins, let alone a confirmation of earlier purification of the soul of sins. ${ }^{29}$

In the Gospel of Mark, the arrival of the people onto the banks of the Jordan and their baptism in that river, together with the confession of their sins, are presented as a proper response to John's activity, which is thus shown as attaining its objective. John himself speaks of baptism with water as a completed activity - in the past tense: "I baptized ( $\dot{\varepsilon} \gamma \omega \dot{\varepsilon} \beta \dot{\alpha} \pi \tau \iota \sigma \alpha)$ " (Mark 1:8). Again, the attitude of all the people is presented in positive light in the Evangelist's comment on the knowledge of the Sanhedrin members that John was widely regarded as a prophet (Mark 11:32).$^{30}$ The depictions by the other Synoptics are different. The confession of sins is not unequivocally positive in the Gospel of Matthew because of the admission of sin by Judas (Matt 27:4). In the first Gospel, the general call for repentance (as in Matt 3:2) comes together with the threat for those who fail to respond to this call (Matt 3:7-10). In the third Gospel, specific actions are required of John's followers (Luke 3:10-14). John's activity is not finished in both Synoptic versions: John speaks of his baptism not as of finished activity, but as of an ongoing one - in the present tense: "I baptize" ( $\beta \alpha \pi \tau i \zeta \omega)$ (Matt 3:11; Luke $3: 16$ ). The repentance required by John is a goal not yet achieved by the recipients of baptism in the Jordan River.

28 The coming is the activity of the redeeming God: He comes with the power to save His people (Isa 40:10); He comes to gather all peoples and languages (Isa 66:18). Messianic hopes are placed in the final one, who comes in the name of the Lord (Ps 118:26), who comes as the humble King (Zech 9:9) and the Son of Man (Dan 7:13).

29 This second meaning of washing the body with water is attributed by Josephus Flavius: $\dot{\alpha} \lambda \lambda^{\prime} \dot{\varepsilon} \varphi$ '

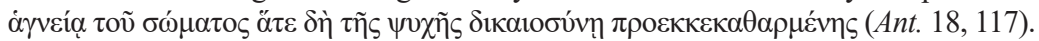

30 In the Gospel of Mark, the narrator himself presents this belief of the crowd, while in two other Synoptics this opinion is attributed to the crowd by Jesus' opponents (Matt 21:26; Luke 20:6). 
The confession of sins that accompanies John's ritual is therefore, in the Gospel of Mark, a good recognition of the need to amend the relationship with God. What is the significance of the connection between learning about the need to change this relationship and the ritual of washing with water? Such a connection, suggested by the syntax of the sentence,${ }^{31}$ has a counterpart in the central chapters of the middle book of Torah. They convey the principles of purity which are linked to matters directly concerning life and its preservation: food, birth, health, housing, reproduction (Lev 11-15). Such an approach corresponds to the Semitic concept of the unity of a human being in body and spirit. ${ }^{32}$ The obligation to distinguish between what is clean and unclean begins with a specific requirement imposed only on Aaron and his sons so that they could officiate the worship, which is then extended to cover all Israelites (Lev 10:9-11). This kind of diagnosis does not equate to regaining purity, as evidenced by repetitions in the regulations about purification. After the references to washing clothes, washing other items, or ritual bathing, the phrase "shall be unclean until evening" is repeated (Lev 11: 25.28.40; 15:5-11.16-19.21-23.27; cf. Num 19:7.8.10.21.22). Such a structure means that the ritual of washing does not automatically equate with purification. An explicit statement about regaining purity after an allotted period of time have elapsed is repeated twice (Lev 11:32; 17:15). The consequence of neglecting the obligatory ablution is mentioned once: in this case, the arrival of the indicated time of day does not bring purification to the negligent people but results in them becoming guilty of transgression (Lev 17:16). The time of purification is set by God, and the actions of a human being alone are not sufficient to achieve it. If ablution is not always explicitly mentioned, purification always occurs when the appointed time comes. From the moment of washing with water or immersing in it, until evening, people and objects are officially recognized as unclean and thus awaiting purification. The above distinction - between the recognition of an inappropriate condition and the announcement of its change - is also visible in the description of John's activity. Already in the summary introduction to the description, two activities are presented as parallel: baptism as washing with water and baptism focused on purification. In the extension of this brief description, those two baptisms turn out to be - against the background of the purity requirements in Leviticus - related and mutually complementary like diagnosis and therapy. ${ }^{33}$

31 Analogous juxtapositions of a verb in the past imperfect tense with a participle form reflect the re-

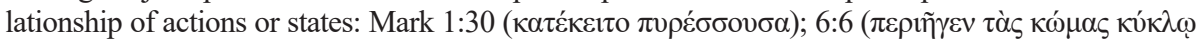

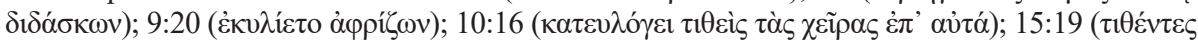

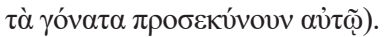

32 Cf. W.F. Flemington, The New Testament Doctrine of Baptism (London: SPCK 1957) 10.

33 More on the importance of the Book of Leviticus for the interpretation of the relationship between John's baptism with water and the Jesus' baptism in the Holy Spirit in A. Malina, Chrzest 
At this point, and certainly not of secondary interest, it is worth to recall that the texts of Matthew and Luke, and even a fragment of Josephus Flavius, do not blur the distinct boundaries between washing with water and forgiveness of sins. ${ }^{34}$ If the summary description of Mark may cause some difficulties due to the strict juxtaposition of the two types of John's activities, its extension clearly distinguishes them and, at the same time, associates one to the other.

\subsection{Significance of the Description Referring to John (Mark 1:6)}

Only the Gospel of Mark separates the extensions of the descriptions of two types of John's activities - baptism with water (Mark 1:5) and preaching (Mark 1:7-8) - by describing John's clothing and diet as activities appropriate to the place where he stayed (Mark 1:6). This narrative has a different function than that of Matthew's parallel description. The first Gospel provides information about John's attire and food (Matt 3:4). Mark, on the other hand, pays attention to what he wore and ate. The difference is subtle yet important. The characteristics presented by Matthew evoke associations with the prophets: John's clothing and food resembled Elijah's (although only a leather belt is mentioned in $2 \mathrm{Kgs} 1: 8$ ) and that of prophets in general (Zech 13:4). This description fits in with the clear prophetic character of his message, which consists of a call to repentance, justified by a quotation from Isaiah (Matt 3:2-3; cf. Isa 40:3). On the other hand, Mark's parallel description agrees with the meaning of John's whereabouts: wilderness understood as an uninhabited place. ${ }^{35}$ Thus, for Mark, this verse serves as a link between the descriptions of John's two activities: baptism (Mark 1:5) and preaching (Mark 1:7-8), which are conducted in one place and at the same time, and - most importantly - have one addressee. Matthew and Luke do not have such a combination of these two activities of John, because they do not have an analogous transition from summarizing these two activities (Mark 1:4) to elaborating on this description (Mark 1:5.7-8).

Jezusa w czterech Ewangeliach. Studium narracji i teologii (Katowice: Księgarnia św. Jacka 2007) 224-229. The baptism of Jesus in the Jordan River, in this fundamental sense, has the same result as the baptism of all other people: learning the truth about the relationship of the ones washed with water and God. Unlike all the others who are immersed in the Jordan River, the essence of this truth, in the case of Jesus, is positive: His relationship with God is perfect, as evidenced not only by His lack of confession of sins but, above all, by the voice from heaven (Mark 1:11); ibidem, 275-276.

34 As was already shown above in point 1.

35 And not the place defined by the name of the desert region (Matt 3:1 "the desert of Judea") to which the inhabitants of the adjacent lands go, which is presented right after the description of John's appearance (Matt 3:5). 


\subsection{Extension of the Description of Preaching (Mark 1:7-8)}

A brief introduction to John's words, quoted in direct speech, refers to the concise description of his activities. The same verb forms - "preaching" ( $ү \rho v ́ \sigma \sigma \omega v)$

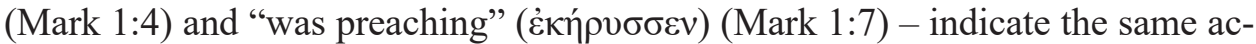
tion. If John were to preach his baptism in the summary verse, such an approach would be the exception in this Gospel, which emphasizes preaching denoted by the verb $\kappa \eta \rho v ́ \sigma \sigma \varepsilon v^{36}$ the most. The subjects of the action described by this verb are various persons: John (Mark 1:4.7), Jesus (Mark 1:14.38.39), His disciples (Mark $3: 14 ; 6: 12 ; 13: 10 ; 14: 9$; the disciples are his subject also according to the longer ending of the canonical figure of Mark at 16:15.20), healed (Mark 1:45; $5: 20 ; 7: 36)$. Despite the diversity of subjects, the content of the proclamation always refers to Jesus and his deeds: from his arrival in Galilee, Jesus himself preaches the Gospel of God (Mark 1:14; without clearly indicating the subject in Mark 1:38.39); after his resurrection, his disciples also preach the Gospel (Mark 13:10; 14:9). The Gospel they preach is His Gospel (Mark 1:1). They will be persecuted because of it and because of Him (Mark 8:35; 10:29), and before that, they are sent by Him to preach (Mark 3:14; 6:12). The healed preach about miraculous healings performed by Jesus (Mark 1:45; 5:20; 7:36). If in all these places the subject of the proclamation is related to Jesus and his activity, then also in the first mentions the content of John's proclamation points to the same person and to his activity, more specifically to Jesus' future baptism of repentance for the forgiveness of sins, and not John's activity, which is water baptism in Jordan.

The content of the proclamation marked in this way is also identical. In the summary description, it is presented by the expression "baptism of repentance for the remission of sins," while in John's message quoted in direct speech the announcement: "He will baptize you in the Holy Spirit." The addressees of this one message are the same persons who are the subjects of: egress from their dwellings into the desert, receiving baptism in the Jordan, and confessing sins (Mark 1:5). The unity of John's message is confirmed by the fact that he juxtaposes the one who follows him and his future baptism with his position (Mark 1:7) and with his completed baptism (Mark 1:8). Those who receive one baptism from John with water also receive from him the proclamation of one baptism that they will receive in the future.

Readers of the Gospel of Mark find it difficult to identify the baptism preached by John because they depend on parallel texts that seem to present John's work in greater depth and detail. The first Gospel does not allow for the identification of the content marked by the phrase "baptism of repentance for the remission of sins" at all, because it does not contain that expression. On the other hand,

36 In Synoptic narrative texts this verb appears in: Matt - 9 times, Mark - 14, Luke - 9; Acts -8. 
the narrative of John's activity in the third Gospel, much broader and more diversified than its concise description in the Gospel of Mark, makes the identity of the baptism of repentance for the forgiveness of sins and of the baptism in the Holy Spirit less visible for at least three reasons:

1) It is more difficult to link the baptism proclaimed by John (Luke 3:3) with his predicted future baptism in the Holy Spirit and fire (Luke 3:16), because there are twelve verses between the two texts, while in the text of Mark there are only three verses.

2) At the beginning of the description of John's activity, the same verb denoting

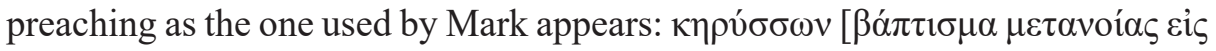
$\ddot{\alpha} \varphi \varepsilon \sigma ı v \dot{\alpha} \mu \alpha \rho \tau \imath \tilde{\omega} v]$ (Luke 3:3). However, in Luke it is not repeated in the introduction to the announcement of future baptism - it has two other verba dicendi: $\dot{\alpha} \pi \varepsilon \kappa \rho i ́ v \alpha \tau o ~ \lambda \varepsilon ́ \gamma \omega v$ (Luke 3:16), while in Mark it is used again in the short intro-

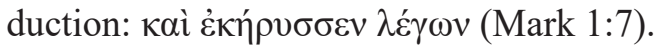

3) John's words, which characterize the two baptisms, are a response to the people's pondering of their possible messianic identity (Luke 3:15), not a speech to those who were baptized by him in the Jordan and confessed their sins. John speaks of water baptism as an action still lasting - in the present tense: "I am baptizing" ( $\beta \alpha \pi \tau i \zeta \omega)$ (Luke 3:16; and likewise Matt 3:11).

Thanks to the conciseness and lower diversification of Mark's text, it is easier to discern the identity of two baptisms in it: the baptism of repentance for the remission of sins and the baptism in the Holy Spirit. It is necessary to read this text without harmonizing it with parallel passages. Mark does not present any activity of the people other than reception baptism and confession. Their activity does not bring purification or establish a proper relationship with God. Confessing sins is first and foremost a recognition of the need for their forgiveness. Its fulfilment does not depend on their activity or even on John's activity. The texts of the second Gospel which treat about the forgiveness of sins leave no doubt that the relationship with God, recognized as defective by the people washed in Jordan, can only be amended by God Himself (Mark 2:7; 3:28; $11: 25$ ). Nothing in the completed activity of John can be equated with the baptism of repentance for the forgiveness of sins, which would be carried out while it lasted. This baptism is yet to come. However, the confession of sins is important on account of the proclaimed baptism of repentance: this act, which accompanies water baptism directs people to the person indicated to them by John and who is to make the necessary cleansing in the near future. Thanks to John's activity, people not only recognize the need to amend their relationship with God but also receive a promise of its change in the announcement of imminent baptism in the Holy Spirit. ${ }^{37}$

37 For this reason, it is not enough to say that, through John's baptism, the baptized will be forgiven their existing sins in God's future judgment - as in U. Schnelle, "Taufe," Theologische Realenzyklopädie (eds. G. Krause et al.) (Berlin - New York 2001) XXXII, 664. 


\section{Conclusion}

The identification of the baptism of repentance for the remission of sins with the baptism in the Holy Spirit is supported by the compact structure of the description of John's activity, viewed as coherent in the Gospel of Mark. The identification of the content of the baptism proclaimed by him ("the baptism of repentance for the remission of sins") with the baptism in the Holy Spirit ("He will baptize you in the Holy Spirit") links this content with the situation of the addressees of John's message: the announcement of the future baptism is addressed to those who are baptized with water and confess their sins. To those who have already confessed their sins, John does not speak of his baptism as an ongoing process, but proclaims that his baptism with water is already a thing of the past. The content of his address in the Gospel of Mark is not a call to repentance, which consists in a change of behaviour, as the parallel texts portray it. The content of his preaching is the announcement of what they need as sinners: the coming of the baptizer in the Holy Spirit.

The relationship between the baptism preached by John and the activity accomplished in the Holy Spirit is also confirmed at the level of the further Gospel narrative. If the baptism of repentance for the forgiveness of sins is identical to the baptism in the Holy Spirit, then such a connection should be apparent also to the addressees of the Baptist's activity, among whom all the inhabitants of Jerusalem were. It is upon learning about this relationship that the logic is based in Jesus' response given to the scribes who, having just come from Jerusalem, accuse Him of a pact with the leader of the unclean spirits (Mark 3:22). John also preached the baptism in the Holy Spirit as the baptism for the forgiveness of sins to them, hence their rejection of Jesus' activity accomplished in that Spirit already deprives them of the forgiveness of sins in the present (Mark 3:28-30).

Translated by Grzegorz Knyś

\section{Bibliography}

Aland, K. (ed.), Synopsis Quattuor Evangeliorum. Locis parallelis evangeliorum apocryphorum et patrum adhibitis, 15 ed. (Stuttgart: Deutsche Bibelgesellschaft 1996).

Baert, B., "The Dancing Daughter and the Head of John the Baptist (Mark 6:14-29) Revisited. An Interdisciplinary Approach," Louvain Studies 38/1 (2014) 5-29.

Bock, D., Mark (Cambridge: Cambridge University Press 2015).

Comfort, P.W., Encountering the Manuscripts. An Introduction to New Testament Paleography \& Textual Criticism (Nashville: Broadman \& Holman 2005). 
Costin, T., Il perdono di Dio nel Vangelo di Matteo. Uno studio esegetico-teologico (Roma: Editrice Pontificia Università Gregoriana 2006).

Cuvillier, É., L'évangile de Marc (Paris - Genève: Labor et Fides 2002).

Dillon, R.J., "The Benedictus in Micro- and Macrocontext," The Catholic Biblical Quarterly 68 (2006) 457-480.

Donahue, J.R. - Harrington, D.J., The Gospel of Mark (Collegeville, MN: Liturgical Press 2002).

Dschulnigg, P., Das Markusevangelium (Stuttgart: Kohlhammer 2007).

Dunn, J.D.G., Jesus Remembered (Grand Rapids, MI: Eerdmans 2003).

Edwards, J.R., The Gospel According to Mark (Grand Rapids, MI - Cambridge: Eerdmans 2002).

Ferguson, E., Il battesimo nella chiesa antica. Storia, teologia e liturgia nei primi cinque secoli. I. I primi due secoli (Brescia: Paideia 2014).

Filannino, F., Tra il precursore e i discepoli. La missione di Gesù nel vangelo di Marco (Roma: Gregorian \& Biblical Press 2019).

Flemington, W.F., The New Testament Doctrine of Baptism (London: SPCK 1957).

Focant, C., L'évangile selon Marc (Paris: Cerf 2004).

France, R.T., The Gospel of Mark. A Commentary on the Greek Text (Grand Rapids, MI - Cambridge: Eerdmans 2002).

Grasso, S., Luca (Roma: Borla 1999).

Grasso, S., Vangelo di Marco. Nuova versione, introduzione e commento (Milano: Paoline 2003).

Gruenwald, I., "The Baptism of Jesus in Light of Jewish Ritual Practice," Neotestamentica $50 / 2$ (2016) 301-325.

Guttenberger, G., Das Evangelium nach Markus (Zürich: Theologischer Verlag 2017).

Hahn, F., Theologie des Neuen Testaments. I. Die Vielfalt des Neuen Testaments. Theologiegeschichte des Urchristentums (Tübingen: Mohr Siebeck 2002).

Hartman, L., "Into the Name of the Lord Jesus". Baptism in the Early Church (Edinburgh: Clark 1997).

Keener, C.S., The Historical Jesus of the Gospels (Grand Rapids, MI - Cambridge: Eerdmans 2009).

Lane, W.L., The Gospel According to Mark. The English Text with Introduction, Exposition and Notes (Grand Rapids, MI: Eerdmans 1974).

Légasse, S., "L'autre «baptême» (Mc 1,8; Mt 3,11; Lc 3,16; Jn 1,26.31-33)," The Four Gospels 1992. Festschrift Frans Neirynck (eds. F. van Segbroeck et al.) (Leuven: University Press 1992) I, 256-273.

Malina, A., Chrzest Jezusa w czterech Ewangeliach. Studium narracji i teologii (Katowice: Księgarnia św. Jacka 2007).

Malina, A., "Le ragioni del silenzio richiesto ai discepoli (Mc 8,30; 9,9)," Antonianum 91/1 (2016) 177-193.

Marcus, J., John the Baptist in History and Theology (Columbia, SC: University of South Carolina 2018).

Marcus, J., Mark 1-8. A New Translation with Introduction and Commentary (New York: Doubleday 2000).

Marshall, I.H., The Gospel of Luke. A Commentary on the Greek Text (Grand Rapids, MI: Paternoster Press - Eerdmans 1978).

Mascilongo, P., Il Vangelo di Marco. Commento esegetico e teologico (Roma: Città Nuova 2018).

Meier, J.P., A Marginal Jew, Rethinking the Historical Jesus. II. Mentor, Message, and Miracles (New Haven, CT - London: Yale University Press 1994). 
Meynet, R., Il Vangelo secondo Luca. Analisi retorica (Bologna: Dehoniane 2003).

Morales Ríos, J.H., "Visita e antropologia nel Benedictus (Lc 1,67-79)," Antonianum 94 (2019) 9-37.

Mullins, M., The Gospel of Mark. A Commentary (Dublin: Columba Press 2005).

Puig i Tàrrech, A., "Pourquoi Jésus a-t-il reçu le baptême de Jean?," New Testament Studies $54 / 3$ (2008) 355-374.

Rothschild, C.K., "«Echo of a Whisper». The Uncertain Authenticity of Josephus' Witness to John the Baptist," Ablution, Initiation, and Baptism. Late Antiquity, Early Judaism, and Early Christianity / Waschungen, Initiation und Taufe. Spätantike, Frühes Judentum und Frühes Christentum (eds. D. Hellholm et al.) (Berlin - Boston, MA: De Gruyter 2011) I, 255-290.

Sabourin, L., Il vangelo di Luca. Introduzione e Commento (Roma: Editrice Pontificia Università Gregoriana 1989).

Schenke, L., "Jesus und Johannes der Täufer," Jesus von Nazaret - Spuren und Konturen (eds. L. Schenke et al.) (Stuttgart: Kohlhammer 2004) 84-105.

Schnabel, E.J., Mark. An Introduction and Commentary (Downers Grove, IL: InterVarsity 2017).

Schnelle, U., “Taufe,” Theologische Realenzyklopädie (eds. G. Krause et al.) (Berlin - New York 2001) XXXII, 663-674.

Shafer, G., "John the Baptist, Jesus, and Forgiveness of Sins," Eastern Great Lakes and Midwest Biblical Society Proceedings 26 (2006) 51-67.

Stock, K., Marco. Commento contestuale al secondo Vangelo (Roma: Edizioni ADP 2003).

Sung, C.-H., Vergebung der Sünden. Jesu Praxis der Sündenvergebung nach den Synoptikern und ihre Voraussetzungen im Alten Testament und frühen Judentum (Tübingen: Mohr Siebeck 1993).

Trench, R.C., Synonyms of the New Testament (London: Macmillan 1871).

Trimaille, M., La christologie de saint Marc (Paris: Desclée 2001).

Vette, N. - Robinson, W., "Was John the Baptist Raised from the Dead? The Origins of Mark 6:14-29," The Biblical Annals 9/2 (2019) 335-354.

Wenk, M., Community-Forming Power. The Socio-Ethical Role of the Spirit in Luke - Acts (Sheffield: Sheffield Academic Press 2000).

Witherington III, B., The Gospel of Mark. A Socio-Rhetorical Commentary (Grand Rapids, MI Cambridge: Eerdmans 2001). 
